二層地盤における塩水侵入

Seawater Intrusion in Two-Layered Unconfined Aquifers

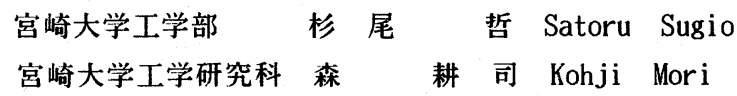

Seawater intrusion is examined on the two-layered unconfined aquifers. Numerical solutions obtained by Residual Flow Procedure show that Dupuit's approximation and Herzberg relation are hardly satisfied near the downstream end. With apprication of velocity shape factor, analytical solutions are derived on flow rate and on the shapes of free surface and fresh-saltwater interface. Analytical positions of fresh-saltwater interface agree with experimental position and numerical one. From the simuled results, it is clarified that seawater easily intrude to the two-layered aquifers in case that the layers in higher permeability overlie on the layers in lower permeability.

Keywords : two-layered unconfined aquifer, seawater intrusion, Dupuit's approximation

1.まえがき

海岸浸透地盤において、地下水の塩水化障害を起こすことなく地下水資源を有効に利用するためには、地 盤への塩水侵入特性を理解することが必要である。このため、これまでにも数多くの研究が行われてきたが、 それらのほとんどは、均質等方性の理想的な浸透地盤を対象としたものであり、実際の地盤に多く見られる ような、鉛植方向に種々の透水性の地層が分布する成層地盤についての塩水侵入の検討は少ない。特に、間 に難透水層を挟まずに、上下の浸透層で透水性が異なる成層地盤についての研究は少なく、わすかに佐藤・ 渡辺 ${ }^{1}$ などの研究を見る程度に過ぎない。本研究は、現実的な流れの場での地下密度流の浸透の理論的解明 を図るため、成層地盤の基本となる二層地盤について、準一様流の仮定を拡張した解析を行い、塩水侵入特 性を検討したものである。

\title{
2. 数値解析による地盤内の水頭分布
}

まず、残差流手法(Residual flow procedure)によって構築した不圧浸透層中の鉛直二次元地下密度流の 数値モデル2゙を用いて、二層地盤内の水頭分布を求めた。残差流手法は不圧浸透層内の地下水流動の解法と

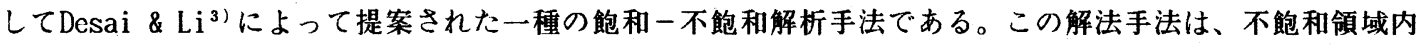
の体積含水率を変数として扱わず、透水係数を圧力の関数と考えることによって、解析を行うものである。 解析上は、負の圧力を持つ領域に小さな透水係数を与えることに よって残差流成分が生じ、この成分を利用して解析することに残 差流手法の特徴がある。この解析手法を、つぎのように考えて、 圀ー 1 の地下密度流の解析に適用した。

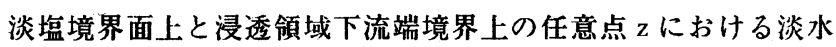
水頭 $\phi$ は、淡水と塩水の密度をそれぞれ $\rho_{\mathrm{t}}, \rho \mathrm{s}$ とすると:

$$
\phi=\mathrm{z}\left(\rho_{\mathrm{s}}-\rho_{\mathrm{f}}\right) / \rho_{\mathrm{f}}=\mathrm{z} \varepsilon
$$

で表され、深さ方向に次第に大きくなる分布を示す。そこで塩水 領域を、淡塩境界面上と浸透領域下流端境界上で、式-1 と同じ 水頭分布を持つ仮想上の淡水領域に変換すると、淡水だけの流れ とみなして全領域を解くことができる゙)。この時、下流端境界に

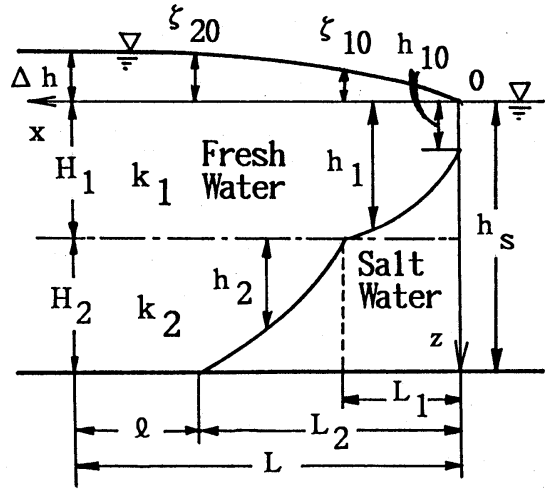

圀-1 二層地盤の解析領域 
作用する圧力よりも低い压力の淡水領域を塩 水領域と考之、塩水領域と混合領域の淡水の 不飽和領域においては、淡塩二層地下水流に おける混合領域内の相对透水(Relative permeability ${ }^{5)}$ )の変化を考虑して、透水係数に 小さな値を与える。解析上は、このことによ つて残差流成分が生ずるから、飽和一不飽和 解析と同じアルゴリズムで、図ー10塩水侵 入問題を解けることになる。

以上の解析手法によって得られた水頭から 解析領域内の等水頭線を求めると図 $-2,3$ の様になる。困一 2 は上層の透水係数 $\mathrm{k}_{1}$ と下 層の透水係数 $\mathrm{k}_{2}$ との比が $\mathrm{k}_{1} / \mathrm{k}_{2}=10$ 、図 -3 は $\mathrm{k}_{1} / \mathrm{k}_{2}=1 / 100$ )場合を示している。

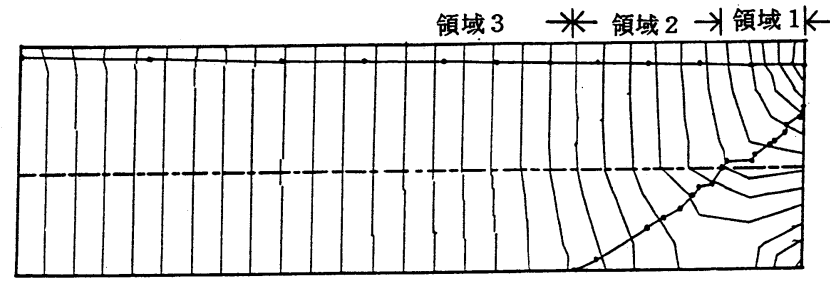

図-2 $\quad k_{1} / k_{2}=100$ 等水頭線 $[(\Delta h+h s) / h s=1.075]$

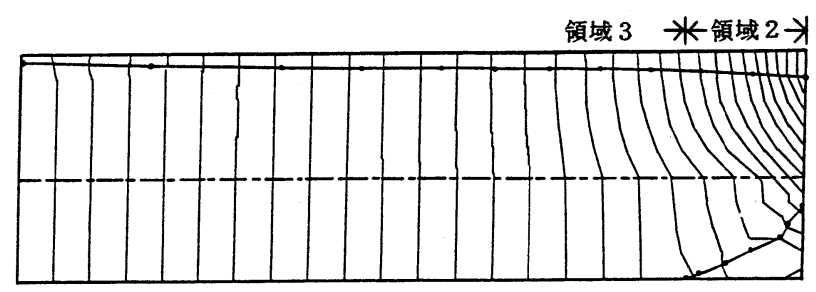

図- $\left.3 \quad k_{1} / k_{2}=1 / 100\right)$ 等水頭線 $((\Delta h+h s) / h s=1.075)$

\section{3. 準一様流の仮定を㧓張した理論解析}

図一 2，3の淡塩境界面が形成される下流域においては、等水頭線が海曲しており、この部分では準一様 流の仮定が成立しにくいと考えられる。そこで準一様流の仮定に基づいた佐藤・渡辺の理論解を、Anwarの velocity shape factor ${ }^{6)}$ 準用した水頭分布係数を適用して修正することを考える。

いま図-1 の浸透領域内の任意点における速度成分を $\mathrm{u}(\mathrm{x}, z)=\mathrm{U}(\mathrm{x}) \cdot \mathrm{S}(\mathrm{z})$ で表現し、U(x)をその鉛直断面 内の、その点を含む層内での平均流速、 $\mathrm{S}(z)$ を水頭分布に係わる值とする。これを $0 \leqq \mathrm{x} \leqq \mathrm{L}_{1}$ の領域 1 につ いて鉛直方向に積分し、 $h_{1}=\zeta / \varepsilon$ とおいて、連続式を次のように表す。

$$
\mathrm{Q}=\int_{-\zeta}^{h_{1}} \mathrm{u}(\mathrm{x}, z) \mathrm{d} z=\mathrm{Sv}_{1} \cdot \mathrm{U}_{1}(\mathrm{x}) \cdot \zeta(1+1 / \varepsilon) \quad:\left(0 \leqq \mathrm{x} \leqq \mathrm{L}_{1}\right)
$$

ここに $\mathrm{Sv}_{1}=\frac{1}{\zeta(1+1 / \varepsilon)} \int_{-\zeta}^{h_{1}} \mathrm{~S}(z) \mathrm{d} z$ で、Dupuitの仮定とHerzbergの式を合わせて修正する係数であり、 水頭分布係数と呼ぶことにする。

$\mathrm{L}_{1} \leqq \mathrm{x} \leqq \mathrm{L}_{2}$ の領域 2 および $\mathrm{L}_{2} \leqq \mathrm{x} \leqq \mathrm{L}$ の領域 3 においても、同様に次の様に表す。

$$
\begin{array}{ll}
\mathrm{Q}=\mathrm{SV}_{1} \cdot \mathrm{U}_{1}(\mathrm{x}) \cdot\left(\zeta+\mathrm{H}_{1}\right)+\mathrm{SV}_{2} \cdot \mathrm{U}_{2}(\mathrm{x}) \cdot\left(\zeta / \varepsilon-\mathrm{H}_{1}\right) & :\left(\mathrm{L}_{1} \leqq \mathrm{x} \leqq \mathrm{L}_{2}\right) \\
\mathrm{Q}=\mathrm{SV}_{1} \cdot \mathrm{U}_{1}(\mathrm{x}) \cdot\left(\zeta+\mathrm{H}_{1}\right)+\mathrm{SV}_{2} \cdot \mathrm{U}_{2}(\mathrm{x}) \cdot \mathrm{H}_{2} & :\left(\mathrm{L}_{2} \leqq \mathrm{x} \leqq \mathrm{L}\right)
\end{array}
$$

運動式はダルシー式を用い、それぞれの層内の平均流速を、その鉛直断面の水面勾配を用いて次式で表す。

$$
\mathrm{U}_{1}(\mathrm{x})=-\mathrm{k}_{1} \partial \zeta / \partial \mathrm{x}, \quad \mathrm{U}_{2}(\mathrm{x})=-\mathrm{k}_{2} \partial \zeta / \partial \mathrm{x}
$$

式(2)に式(5)を代入して水平方向に積分し、 $x=0$ で $h_{1}=h_{10}, \zeta=\varepsilon h_{10}$ とおくと、領域 1 における自由地 下水面と淡塩境界面がそれぞれ次式で表される。

$$
\begin{aligned}
& -\mathrm{Q} \cdot \mathrm{x}=\mathrm{k}_{1} \mathrm{SV}_{1}(1+\varepsilon)\left(\zeta^{2}-\varepsilon^{2} \mathrm{~h}_{10}{ }^{2}\right) / 2 \varepsilon \\
& -\mathrm{Q} \cdot \mathrm{x}=\mathrm{k}_{1} \mathrm{SV}_{1} \varepsilon(1+\varepsilon)\left(\mathrm{h}_{1}{ }^{2}-\mathrm{h}_{10}{ }^{2}\right) / 2
\end{aligned}
$$

同様に、式(3)に式(5)を代入し、 $x=L_{1}$ で $h_{1}=H_{1}, \zeta=\zeta_{10}$ とおくと、領域 2 にいて

$$
\begin{aligned}
& -\mathrm{Q}\left(\mathrm{x}-\mathrm{L}_{1}\right)=\left(\varepsilon \mathrm{k}_{1} \mathrm{SV}_{1}+\mathrm{k}_{2} \mathrm{~Sv}_{2}\right)\left(\zeta^{2}-\zeta{ }_{10}{ }^{2}\right) / 2 \varepsilon+\left(\mathrm{k}_{1} \mathrm{~Sv}_{1}-\mathrm{k}_{2} \mathrm{SV}_{2}\right) \mathrm{H}_{1}\left(\zeta-\zeta{ }_{10}\right) \\
& -\mathrm{Q}\left(\mathrm{x}-\mathrm{L}_{1}\right)=\left(\varepsilon \mathrm{k}_{1} \mathrm{SV}_{1}+\mathrm{k}_{2} \mathrm{~Sv}_{2}\right) \varepsilon \mathrm{h}_{2}{ }^{2} / 2+\mathrm{k}_{1} \mathrm{SV}_{1} \varepsilon(1+\varepsilon) \mathrm{h}_{2} \mathrm{H}_{1}
\end{aligned}
$$

式(4)に式(5)を代入し、 $x=L_{2}$ で $\zeta=\zeta_{20}, x=\mathrm{L}$ で $\zeta=\Delta h$ とおくと、領域 3 について 


$$
\begin{aligned}
& -\mathrm{Q}(\mathrm{L}-\mathrm{x})=\left(\mathrm{k}_{1} \mathrm{~Sv}_{1} \mathrm{H}_{1}+\mathrm{k}_{2} \mathrm{~Sv}_{2} \mathrm{H}_{2}\right)(\Delta \mathrm{h}-\zeta)+\mathrm{k}_{1} \mathrm{~Sv}_{1}\left(\Delta \mathrm{h}^{2}-\zeta^{2}\right) / 2 \\
& -\mathrm{Q}\left(\mathrm{L}-\mathrm{L}_{2}\right)=\mathrm{k}_{1} \mathrm{~Sv}_{1}\left\{\left(\mathrm{H}_{1}+\Delta \mathrm{h}\right)^{2}-\left(\mathrm{H}_{1}+\zeta_{20}\right)^{2}\right\} / 2+\mathrm{k}_{2} \mathrm{~Sv}_{2} \mathrm{H}_{2}\left(\Delta \mathrm{h}-\zeta_{20}\right)
\end{aligned}
$$

が得られる。領域 3 においては、等水頭線が鉛直な直線であることから、式(11)で $\mathrm{Sv}_{1}=\mathrm{Sv}_{2}=1$ とおき、 $\mathrm{L}-\mathrm{L}_{2}=\ell$ とおくと、次式のような淡水流量の算定式を得る。

$$
|\mathrm{Q}|=\mathrm{k}_{1} \frac{\left(\mathrm{H}_{1}+\Delta \mathrm{h}\right)^{2}-\left(\mathrm{H}_{1}+\zeta_{20}\right)^{2}}{2 \ell}+\mathrm{k}_{2} \mathrm{H}_{2} \frac{\Delta \mathrm{h}-\zeta_{20}}{\ell}
$$

さらに、式(12)を近似的に全領域に拡張して $\ell \rightarrow \mathrm{L} ， \zeta_{20} \rightarrow \varepsilon \mathrm{h}_{10}$ とおき替えると、次式を得る。

$$
|Q|=k_{1} \frac{\left(H_{1}+\Delta h\right)^{2}-\left(H_{1}+\varepsilon h_{10}\right)^{2}}{2 L}+k_{2} H_{2} \frac{\Delta h-\varepsilon h_{10}}{L}
$$

次に $h_{10}$ を求める。領域 1 において、鉛直流速成分を $w(x, z)$ とおくと、連続式とDarcy式は

$$
\partial \mathrm{u} / \partial \mathrm{x}+\partial \mathrm{w} / \partial \mathrm{z}=0 \quad \text { (14) } \quad \mathrm{w}=-\mathrm{k}_{1} \partial\left(\left(\mathrm{p} / \rho_{\mathrm{f}} \mathrm{g}\right)-\mathrm{z}\right) / \partial \mathrm{z}
$$

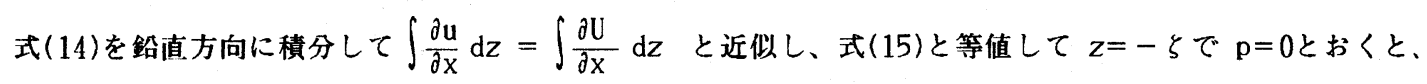

$$
\mathrm{p} / \rho_{\mathrm{t}} \mathrm{g}=\zeta+z+\left(\mathrm{Q}(\zeta+z) / \mathrm{k}_{1} \mathrm{SV}_{1}\right)^{2}(1+\varepsilon) / \varepsilon\left(\zeta+\mathrm{h}_{1}\right)^{3}
$$

$\mathrm{x}=0, z=\mathrm{h}_{1}$ 。において、水圧を領域外側の海水圧と等値すると、 $\mathrm{h}_{10}$ 。が次の様に求まる。

$$
\mathrm{h}_{10}=\frac{\mathrm{Q}}{\mathrm{k}_{1} \mathrm{SV}} \frac{1}{\varepsilon} \sqrt{\frac{1+\varepsilon}{2}}
$$

したがって、式(13)，(17)を連立させて $Q ， h_{1}$ 。を求めると、自由地下水面の形状が式(6),(8)および(10)か ら算定され、淡塩境界面の形状が式(7),(9)から算定できる。

次に、上層の透水性が下層より低い場合、図ー3の様に、淡水の流出面が下層に現れる場合がある。この 場合、 $0 \leqq \mathrm{x} \leqq \mathrm{L}_{2}$ の領域 2 では、式(3)に式(5)を代入し、 $\mathrm{x}=0$ で $\mathrm{h}_{2}=\mathrm{h}_{20}, \zeta=\varepsilon\left(\mathrm{H}_{1}+\mathrm{h}_{20}\right)$ とおくと、

$$
\begin{aligned}
& -\mathrm{Q} \cdot \mathrm{x}=\left(\varepsilon \mathrm{k}_{1} \mathrm{SV}_{1}+\mathrm{k}_{2} \mathrm{~Sv}_{2}\right)\left\{\zeta^{2}-\varepsilon^{2}\left(\mathrm{H}_{1}+\mathrm{h}_{20}\right)^{2}\right\} / 2 \varepsilon+\left(\mathrm{k}_{1} \mathrm{~Sv}_{1}-\mathrm{k}_{2} \mathrm{SV}_{2}\right) \mathrm{H}_{1}\left\{\zeta-\varepsilon\left(\mathrm{H}_{1}+\mathrm{h}_{20}\right)\right\} \\
& -\mathrm{Q} \cdot \mathrm{x}=\left(\varepsilon \mathrm{k}_{1} \mathrm{~Sv}_{1}+\mathrm{k}_{2} \mathrm{~Sv}_{2}\right) \varepsilon\left\{\left(\mathrm{H}_{1}+\mathrm{h}_{2}\right)^{2}-\left(\mathrm{H}_{1}+\mathrm{h}_{20}\right)^{2}\right\} / 2+\left(\mathrm{k}_{1} \mathrm{~Sv}_{1}-\mathrm{k}_{2} \mathrm{~Sv}_{2}\right) \mathrm{H}_{1} \varepsilon\left(\mathrm{h}_{2}-\mathrm{h}_{20}\right)
\end{aligned}
$$

となる。なお $\mathrm{L}_{2} \leqq \mathrm{x} \leqq \mathrm{L}$ の領域 3 においては式(10),(11)が成り立ち、式(13)は $\varepsilon \mathrm{h}_{10} \rightarrow \varepsilon\left(\mathrm{H}_{1}+\mathrm{h}_{20}\right)$ と書き替 えて、式(13)'とする。 $h_{1}$ 。については、 $\mathrm{k}_{1} / \mathrm{k}_{2} \fallingdotseq 0$ の場合には、上層を流下する淡水流量を無視して、式(3) を $\mathrm{Q}=\mathrm{SV}_{2} \cdot \mathrm{U}_{2}(\mathrm{x}) \cdot \mathrm{h}_{2}$ と近似し、式(16)と同様に解析して、 $z=\mathrm{H}_{1}$ で $\mathrm{p}=\rho_{\mathrm{f}} \mathrm{g}\left(\mathrm{H}_{1}+\zeta\right)$ とおくと、

$$
\mathrm{p} / \rho_{\mathrm{t}} \mathrm{g}=\zeta+z+\left[\mathrm{Q}\left(\mathrm{z}-\mathrm{H}_{1}\right) / \mathrm{k}_{2} \mathrm{~Sv}_{2}\right]^{2} / \varepsilon \mathrm{h}_{2}{ }^{3}
$$

が得られ、 $\mathrm{x}=0$ において海水圧の境界条件を適用して整理すると次式を得る。

$$
\mathrm{h}_{20}=\frac{1}{2}\left\{\sqrt{\mathrm{H}_{1}{ }^{2}+\frac{2 \mathrm{Q}^{2}}{\mathrm{k}_{2}{ }^{2} \mathrm{SV}_{2}{ }^{2} \varepsilon^{2}}}-\mathrm{H}_{1}\right\}
$$

\begin{tabular}{|c|c|c|c|c|}
\hline \multicolumn{2}{|c|}{$\mathrm{k}_{1} / \mathrm{k}_{2}$} & $0 \leqq x \leq L_{1}$ & $L_{1} \leq x \leq L_{2}$ & $\mathrm{~L}_{2} \leqq \mathrm{x} \leqq \mathrm{L}$ \\
\hline \multirow{2}{*}{$>1$} & $S v_{1}$ & 1.3 & 1.0 & 1.0 \\
\hline & $\mathrm{Sv}_{2}$ & - & 1.0 & 1.0 \\
\hline \multirow{2}{*}{$<1$} & $\mathrm{SV}_{1}$ & - & 1.5 & 1.0 \\
\hline & $\mathrm{Sv}_{2}$ & - & 1.0 & 1.0 \\
\hline
\end{tabular}

この場合には、式(13)'と式(21)を連立させて $\mathrm{Q}, \mathrm{h}_{2}$ 。を求めると、自由地下水面の形状が式(18)と(10)から 算定され、淡塩境界面の形状が式(19)から算定できる。

\section{4. 数値解析結果および実験結果との比較}

水頭分布係数Svがどのような値を示すのかを調べてみよう。 基本的には、等水頭線が鉛值な直線の場合に $\mathrm{Sv}=1$ と置けるこ とを考虑すると、貝 -2 の場合、上層の領域 2 と領域 3 で $\mathrm{SV}_{1}$ $=1$ と近似でき、下層では領域 3 で $\mathrm{Sv}_{2}=1$ と近似できると考 えられる。また圀ー 3 の場合には、領域 $3 て ゙ \mathrm{~Sv}_{1}=\mathrm{Sv}_{2}=1$ と近 似できると考えられる。これらのほかの領域について、種々の 
境界条件について求めた数値解を用いてSvの值を求める と、図ー4〜6のよjになる。図ー4は図-2の領域 1 におけるSV1を求めたもので、下流端付近では大きな値 を示す場合があるが、これらを除いて平均すると $\mathrm{SV}_{1}=$ 1.3 を得る。図一 5 は、図ー 3 の領域 2 における $\mathrm{Sv}_{2}$ を $\mathrm{SV}_{1}=1$ とおいて求めたもので、 $\mathrm{Sv}_{2}=1.0$ と近似できる ことが分かる。圀ー6は逆に $\mathrm{Sv}_{2}=1$ とおいて目ー 3 の 領域 2 の $\mathrm{Sv}_{1}$ を求めたもので、その平均値は $\mathrm{SV}_{1}=1.5 て ゙$ ある。これらをまとめたものが表ー1である。

これらのSvの値を用いて淡塩境界面の形状を求め、数 値解析結果および砂モデルによる実験結果と比較すると、 困ー7の様になる。図中の長く侵入している淡塩境界面 は、 $\mathrm{k}_{1} / \mathrm{k}_{2}=10, \Delta \mathrm{h} / \mathrm{hs}=0.075, \mathrm{~L} / \mathrm{hs}=3.750$ 場合につい て求めたもので、 $\mathrm{SV}_{1}=\mathrm{SV}_{2}=1$ とした場合の形状も合わ せて示している。短い淡塩境界面は、 $\mathrm{k}_{1} / \mathrm{k}_{2}=0.26, \Delta \mathrm{h} / \mathrm{hs}$ $=0.095, \mathrm{~L} / \mathrm{hs}=3.8750$ 場合について求め、実験結果と 比較したものである。本解析結果は実験結果および数値 解析結果と良く一致している。このことから、本解析結 果が荋足できる結果を与えていることが分かる。なお图 一 7 の実験形状は図ー8に示すような透明アクリル板製 の浸透水槽を使用し、上流端と下流端の水位を $43.8 \mathrm{~cm}$ と $40.0 \mathrm{~cm}$ に固定して約 3 時間後の定常に達した淡塩境界面 を観測したものである。塩水は淡塩境界面の形状を観察 するために、過マンガン酸カリウムを用いて着色してい る。このとき、塩水と淡水の比重は $\rho \mathrm{s}=1.028, \rho_{\mathrm{f}}=0.9$ 98である。また上層は $10 \%$ 粒径 $\mathrm{d}_{10}=0.27 \mathrm{~mm} の$ 川砂を充填 して $\mathrm{k}_{1}=0.253 \mathrm{~cm} / \mathrm{s}$ 、下層は $\mathrm{d}_{10}=0.52 \mathrm{~mm}$ の硅砂を充填し て $\mathrm{k}_{2}=0.959 \mathrm{~cm} / \mathrm{s}$ あっった。

\section{5. 解析結果による侵入傾向の検討}

以下に、種々の場合について淡塩境界面の位置を求め、 塩水の侵入傾向を調べてみよう。なお結果を相互に比較 するために、地盤長さLと下流端水位hsは一定とし、hs

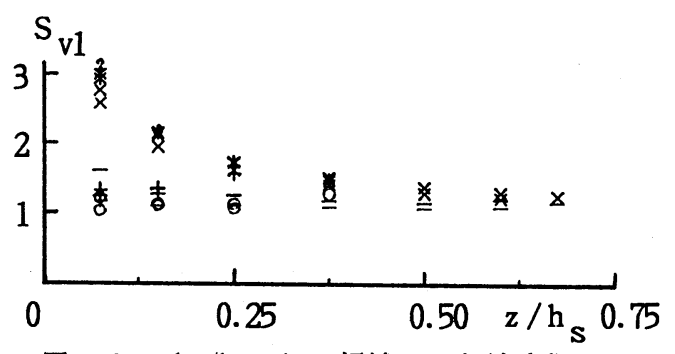

図-4 $\quad \mathrm{k}_{1} / \mathrm{k}_{2}>1$ の領域 1 における $\mathrm{SV}_{1}$

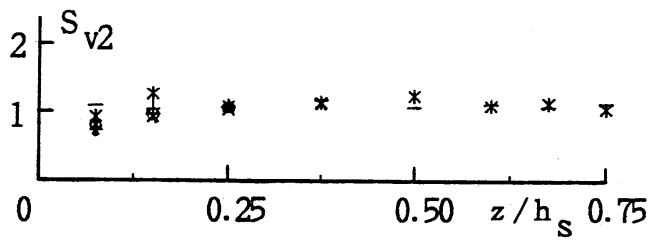

図-5 $\mathrm{k}_{1} / \mathrm{k}_{2}<1$ の領域 2 における $\mathrm{Sv}_{2}$

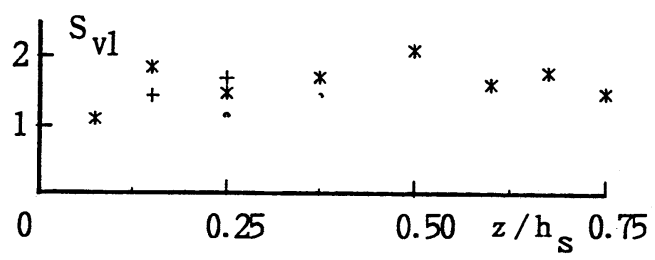

図-6 $\mathrm{k}_{1} / \mathrm{k}_{2}<1$ の領域 2 におけるS

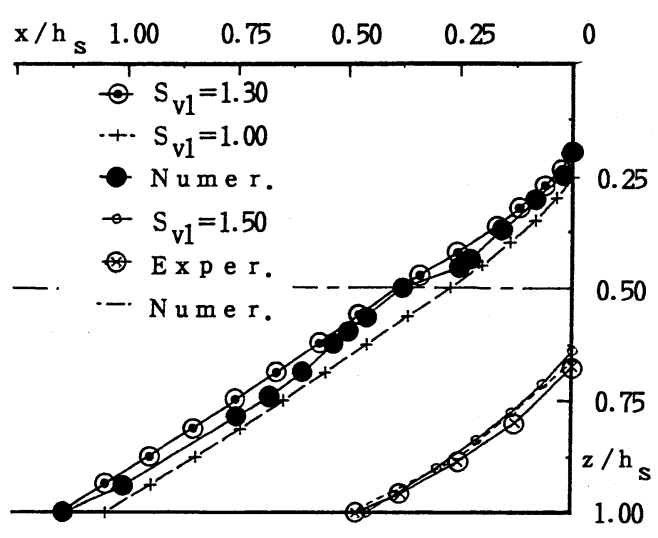

図 -7 実験結果および数值解析結果との比較 で無次元化して、L/hs=3.75 としている。 また塩水および淡水の密度はそれぞれ $\rho \mathrm{s}=$ 1.03、 $\rho_{\mathrm{f}}=1.0$ とする。

（1）透水性の比率による境界面形状の変化 目 - 9, 10は、 $\Delta \mathrm{h} / \mathrm{hs}=0.075$ 場合につい て、上層と下層の透水係数の比率を変えて、 淡塩境界面の形状を求めたものである。圀一 9 は下層が難透水性の場合で、比較のために 均質地盤の結果も合わせて描いている。この

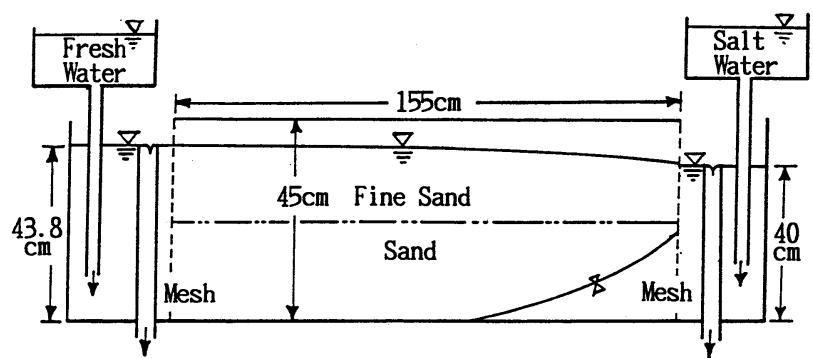

図-8 実験装置の概略図 
困から、下層の透水性の低下に伴って塩水が大きく侵入 することと、 $\mathrm{k}_{1} / \mathrm{k}_{2} \leqq 1 / 100 て ゙ は$ 境界面形状の違いがわず かで、1/100程度の比率で、下層を不透水層とみなせるこ とが分かる。困ー10は上層が難透水性の場合を示してい る。この図から、上層の透水性の低下に伴って塩水が侵 入しにくくなり、この境界条件では上層が下層の約半分 の透水性の場合に、下層だけに侵入するようになること

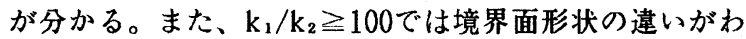
ずかであり、100 程度の比率で、上層を不透水層とみな せることも分かる。

（2）淡水水頭の低下による塩水侵入長の增大

図－11は、上流端の淡水水頭の低下によって、塩水侵 入長がどのように変化するかを求めたものである。この 図から、透水性の比率に係わらず、淡水水頭の低下に伴 って塩水侵入長が增大し、増加の割合は上下流端の水頭 差が小さくなるほど大きくなることが分かる。また、そ の増加を均質地盤の場合と比べると、 $\mathrm{k}_{1} / \mathrm{k}_{2}<1$ の上層 が難透水層の場合に小さく、 $\mathrm{k}_{1} / \mathrm{k}_{2}>1$ の下層が難透水 層の場合に大きくなっている。これらの結果から、下層 が難透水層の二層地盤は均質地盤の場合に比べて塩水の 侵入を受けやすいことが分かる。

\section{(3) 層厚比率の相違による塩水侵入長の変化}

つぎに、上層と下層の層厚比 $\mathrm{H}_{1} / \mathrm{H}_{2}$ の相違により塩水 の侵入長がどのように変化するかを、 $\Delta \mathrm{h} / \mathrm{hs}=0.0750$ 場 合について求めた結果を図ー12に示している。この図か ら、 $\mathrm{H}_{1} / \mathrm{H}_{2}$ が大きくなると、上層の侵入長 $\mathrm{L}_{1}$ は増加するの に対し、下層の侵入長 $\mathrm{L}_{2}$ は著しく減少し、均質地盤の場 合の侵入長に溸近することが分かる。また $\mathrm{L}_{2}$ の減少は上 下層の透水性の違いが小さいほど大きくなっている。し たがって、地盤中にどの程度塩水が侵入しているかは、 浸透層の構成状態により大きく異なることが分かる。

\section{6.むすび}

以上のように、二層地盤における塩水侵入現象につい て、準一様流の仮定とHerzbergの式を補正するための水 頭分布係数を用いた理論解析を行い、淡塩境界面の算定 結果が実験結果や数值解とよく一致することを確認した 上で、塩水の侵入傾向を検討した。その結果、以下のよ うな事柄が明かになった。

1 )均質地盤の場合と比べると、下層が難透水性の二層 地盤では、塩水が大きく侵入する傾向にあり、下層の 透水性が低いほど塩水域が大きく拡大する傾向にある。

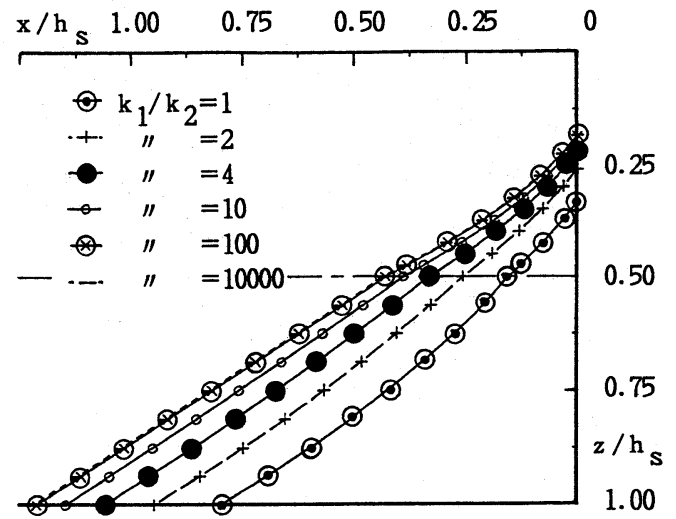

困－9透水性比による境界面位置の変化 下層が難透水性の場合

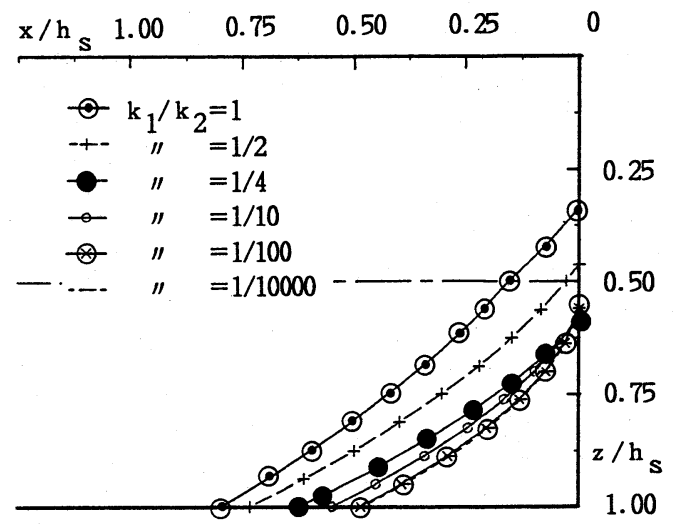

図-10 透水性比による境界面位置の変化 上層が難透水性の場合

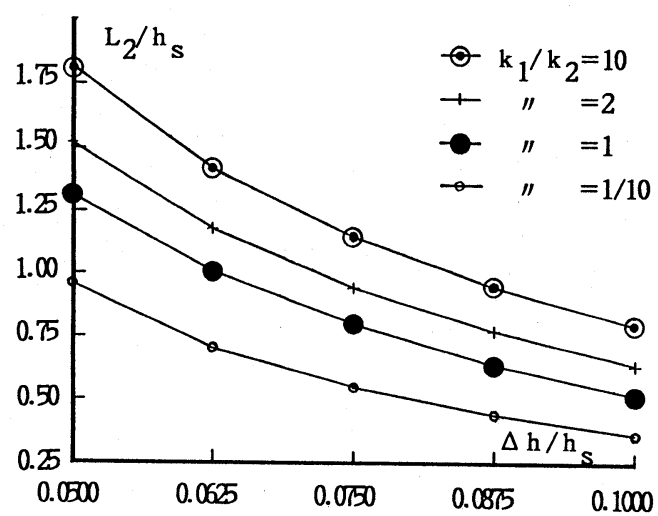

図-11 淡水水頭の相違による侵入長の変化 
2 )上下層の透水係数の比率がほほ100倍になると、透水 性の低い浸透層を不透水層とみなせる。

3 )下層が難透水層の場合には、淡水水頭の低下によっ て、塩水侵入域が大きく增加する。

4 )上下の層厚が異なると、下層の侵入長は大きく変化 する傾向にあり、浸透層の構成状態は塩水侵入に大き く影響する。

これらの傾向は、成層地盤への塩水侵入の基本的特性 と考えられ、多層地盤においても同様の傾向が現れるで あろうから、海岸地盤において地下水資源を利用する際 や管理する際には、これらを十分に考慮することが必要 であろう。

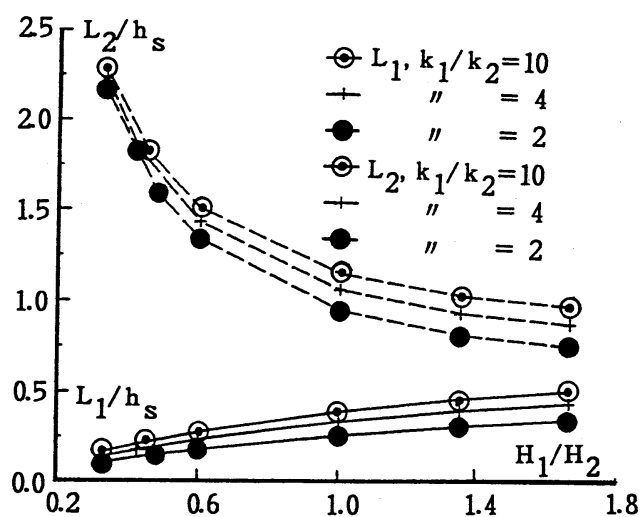

図-12 層厚比の相違による侵入長の変化

\section{参考文献}

1）佐藤邦明·渡辺邦夫:成層帯水層における地下塩水楔の挙動、第19回水理講演会論文集、pp. 127～132、1975.

2) Sugio, S. and C.S. Desai : Residual flow procedure for seawater intrusion in unconfined aquifers, Int. Jour. for Numerical Methods in Eng., Vol.24, pp. 1439 1450, 1987.

3) Desai,C.S. and G.C. Li : A residual flow procedure and application for free surface flow in porous media, Adv. in Water Resour., Vol.6, pp. 27 35, 1983.

4）上田年比古・杉尾哲：暗きょからの淡水注入による淡塩境界面の解析、土木学会論文報告集、第225号、 pp. 43 52、1974.

5) Bear, J. : Two-Liquid Flow In Porous Media, Advances in Hydroscience, Vol.6, Academic Press, pp. $141 \sim 252,1970$.

6) Anwar, H.0. : The effect of a subsurface barrier on the conservation of freshwater in coastal aquifers, Water Res. , Vol. 17, No. 10, pp. 1257 1265, 1983.

7）嶋祐之：地下水（密度流的諸問題）、1971年度水工学に関する夏期研修会講義集、pp. A-8-1, A-8-25. 